\title{
The University between Theory and Practice. How Romanian Aspiring University Leaders Understand the University
}

\author{
Sonia Pavlenko (University Babeș-Bolyai, Centre of University Strategy \\ and Quality Management, e-mail: sonia.pavlenko@ubbcluj.ro, \\ Cristina Bojan (University Babeș-Bolyai, Faculty oh Psychology and \\ Educational Sciences, e-mail: bochristro@yahoo.com)
}

\begin{abstract}
The debate regarding the essence of the university has been going on for centuries. Certain elements of its definition may be age (or century) -specific, illustrating the university's adaptation to the contemporary needs of the society, while others are invariable throughout the centuries. Therefore, it is always a challenge to define the common elements defining the university, applicable at the time of investigation. Our article focuses on the question: How do individuals running for leadership positions in Romanian higher education see/understand the university?. We consider them to be highly informed actors in this field, and their views are a well-informed source of primary information. Firstly, the article reviews existing approaches and definitions of a university, trying both to identify is specifically as a higher education institution and to distinguish it from potentially similar institutions. Then, through qualitative analysis of selected electoral manifestos, it identifies a number of characteristics of the institution. Based on the characteristics identified, the article discusses possible implications of the findings for the Romanian higher education field.
\end{abstract}

Keywords: university, higher education, leadership, discourse analysis 


\section{Introduction}

The debate regarding the essence of the university, the possible definition of what a university is, has been going on for centuries. Certain elements of its definition may be age (or century) -specific, illustrating the university's adaptation to the contemporary needs of the society it belongs to, while others are invariable throughout the centuries. Therefore, it is always a challenge to define the common elements characteristic for the university, applicable at the time of investigation.

Nowadays, almost anyone can say what a university is, especially if one is to apply the well-known phrase: "I know it when I see it" (i.e. I can recognise one when I see one). The term "university" is ever present in the public sphere, especially today, in the knowledge-based society. Universities could even be considered an instrument of soft diplomacy, with many countries competing for "brains" through their universities. Universities are featured in the news, in social media, and in many of the everyday conversations. Nevertheless, one always wonders to what extent regular people work with the full definition of what a university is, and to what extend one understands all the various roles and functions connected to a university. People running for leadership positions in universities can be considered as highly informed actors in this field.

In neighbouring countries (such as Germany, Austria or Hungary), there are clear working differences between a university and other types of higher education institutions. However, in Romania, there is a fair amount of confusion present starting from the legislative level. For example, Romanian Law of Education does not differentiate between universities and other types of higher education institutions. For example, Art. 114 (2) states that "Higher education is organised in universities, academies of studies, institutes, higher education schools and other alike, hereinafter called higher education institutions or universities." However, the literature (classical philosophers, traditional university models, the German, French or English-speaking spaces) offers various definitions for the "university", definitions which alongside identifying the meaning of the concept also help differentiate it from other potentially similar higher education institutions. 
This article attempts to compare the traditional elements composing the definition of the university with the elements present at national (Romanian) level, by looking at a number of texts drafted by people who aim to assume a leadership role in a university, i.e. running for the office of Rector (the highest executive position in a Romanian university). This can also be viewed as an assessment of the impact of the national legislation on individual understandings of concepts, namely on finding could highlight whether those running for the office of Rector stand closer to the traditional, international debates or to the national legislation. One subsequent limitation of such study is the amount of available information pointing to the manner in which would-be leaders conceive their institution as a whole, going beyond the concrete and immediate aims and objectives they proposed for their term in office, were they to be elected. Previous research (Pavlenko \& Bojan, 2013) looked at the manner in which democratic concepts were reflected in the electoral manifestoes of those running for office in 2012, as it was the first time that the electoral process took place according to the provisions of a new law.

Nowadays, with the data from the second round of elections, we believe we can explore more abstract concepts, such as "What is their understanding of a university?" Even though concepts are not the first ones on the debate agenda (indicators and specific objectives are more likely to be found here), we believe that they permeate one's approach and discourse about the university and consequently they can be identified as such in text or coagulated from in between the lines.

\section{Theoretical background}

A university is usually defined as "a high-level educational institution in which students study for degrees and academic research is done" (university, n.d.). This is a rather comprehensive definition, as it highlights some of the basic characteristics of a university, which serve to distinguish it from other similar institutions. Firstly, the university is (i) an institution, and not a company; then (ii) it deals with higher education, and not with other types of education, such as vocational education, or other levels of education (such as primary, secondary, etc.), pointing, at the same time, also towards a certain, more advanced 
degree of knowledge; then (iii) it grants degrees in recognition of the successful completion of a study programme/route and, finally, (iv) it carries out research activities.

Across the Atlantic Ocean, Princeton University's WordNet lexical database suggests three different (yet complementary) definitions for the university. ${ }^{1}$

$>$ First, the university is the body of faculty and students at a university;

$>$ Then, the university is an establishment where a seat of higher learning is housed, including administrative and living quarters as well as facilities for research and teaching;

And last but not least, a university is a large and diverse institution of higher learning created to educate for life and for a profession and to grant degrees.

This triple definition highlights other three fundamental characteristics of a university, namely: ( $v$ ) a university consists of both academics and students; alongside (vi) the space in which the activities take place; moreover, the role of a university is not only to grant degrees and to carry out research activities, but also to (vii) educate for life and for a profession all those who enrol in it. The university is also the place where (viii) universal knowledge is being studied.

Throughout time, the university has been compared with, among others, corporations, companies or civic associations. However, arguing that the university is fully similar to any or all of these would be wrong, as the university is an institution with its own identity. (Some current developments also support approaching the university as one would a company, and in some specific aspects this is viable - however, we should not put an equal sign between a university and other types of institutions or companies.)

In order to be able to identify the essence of the university, Peter Milward (2006, p. 3-7) suggests the following set of questions:

- What is the purpose of a university? (the university is more than just a number of buildings in which the students are trained at a level higher than that of a high school);

\footnotetext{
${ }^{1}$ http://wordnetweb.princeton.edu/perl/webwn? $\mathrm{s}=$ university\&sub=Search+WordNet\&o2=\&o0=1\&o8=1\&01=1\&o7=\&o5=\&o9=\&o6=\&0 $3=\& 04=\& h=$
} 
- To what extent does the university still maintain the contact with universal knowledge? (in the Medieval Age, for instance, one could state, without being in too much error, that Albert the Great, Thomas Aquinas instructor, knew almost everything that there was to know in the world; nowadays, one would be hard pressed to find a university offering courses covering the entire human knowledge. Incidentally, Hilbert (2011) showed that the amount of information available in the world has skyrocketed only taking into account the previous three decades; covering all the information available out there in any limited format or setting would be surely impossible. However, the relationship between university and knowledge is still worth exploring.)

- To what extent do today's universities still maintain the limitations present in the $18^{\text {th }}$ century, where teaching was addressed mainly to students while research was an activity specific mainly to the academics?

In medieval times, the universities were mainly confessional institutions, which did not encourage localism. It was not unusual for a student from Cluj to study at Vienna or a teacher with an Italian background to be teaching at Paris or Oxford. They often even debated similar topics. All this was possible because they all shared the same lingua franca, namely Latin. Most of the times, universities benefited from various privileges granted by rulers or church leaders, or even by the Pope (a Papal Bull was often required to set up a university in the first place). Nevertheless, a significant change took place in Germany at the beginning of the $18^{\text {th }}$ century, when the raison d'etre of the universities transformed from mainly serving the church to predominantly serving the state.

Of course, there are views (old and recent alike) advocating for a university that would pursue only an economic profit. For example, in 1773, Michaelis, an academic at Gottingen University, in his Raisonnement über die protestantischen Universitäten in Deutschland, suggested that universities should be organised as a state economic enterprise, and serve the specific economic needs of the state (for instance, naval training should be available only in the states that border a sea). 
More recently, the manner in which the university is defined seems to gain in diversity. One possible choice for a university is to choose between being an academic enterprise or an entrepreneurial institution. On the one hand, the university should only handle knowledge as an aim in itself, for the sake of knowledge, while, on the other, it should prioritise responding to the needs of the community through educating the required workforce and offering marketable services.

Another pair of alternatives is the apparent choice between being focused on teaching or on research. A research university puts research at the root of all its activities (including teaching and third stream activities), while the alternative is to focus on the teaching process. John Henry Cardinal Newman (1907), for instance, suggested that a fundamental element of university education resides in the fact that students and teachers live in the same space, so that one student's education can only be accomplished not by the mere acquiring of knowledge specific to a certain subject or field, but by sharing the same atmosphere with the teachers. In his famous Discourse $V$, Newman articulates his ideas as follows:

It is a great point then to enlarge the range of studies which a University professes, even for the sake of the students; and, though they cannot pursue every subject which is open to them, they will be the gainers by living among those and under those who represent the whole circle. This I conceive to be the advantage of a seat of universal learning, considered as a place of education. An assemblage of learned men, zealous for their own sciences, and rivals of each other, are brought, by familiar intercourse and for the sake of intellectual peace, to adjust together the claims and relations of their respective subjects of investigation. They learn to respect, to consult, to aid each other. Thus is created a pure and clear atmosphere of thought, which the student also breathes, though in his own case he only pursues a few sciences out of the multitude. He profits by an intellectual tradition, which is independent of particular teachers, which guides him in his choice of subjects, and duly interprets for him those which he chooses. He apprehends the great outlines of knowledge, the principles on which it rests, the scale of its parts, its lights and its shades, its 
great points and its little, as he otherwise cannot apprehend them. (Newman, 1907, p. 101)

Newman suggests that bringing together a group of students and teachers for a (longer) period of time is much more important than a certain exam or teacher for a true higher education. In his wake, campus residency is considered as an important part of a liberal type of education.

This idea was intensively debated in the Transylvanian space as well, at the beginning of the $20^{\text {th }}$ century, when it was decided to set up a new institution of higher education in Cluj. Vasile Pârvan (1919) (who gave the inaugural speech), suggested that the Oxbridge collegiate model be adopted; this would allow the students to acquire, alongside specialised knowledge, a certain type of culture (according to the field they were studying) and to form their characters. A further objective suggested by Pârvan was the promotion of "letters, arts and sciences" pure and applied ones - which would inevitably offer new spiritual values.

Another possible definition of the university is the one quoted by Times Higher Education ${ }^{2}$ and belonging to Peter Knight, who defines higher education "in highly pragmatic terms based on entry standards. It consists, he suggests, of courses that are "difficult, stimulating, challenging and exciting."

The manner in which the university is defined must, however, adapt and reposition itself according to elements present in their socioeconomic context, which might have been more recently included in the debate, included, but not limited to: access, equity, curriculum, student experience, etc. For instance, the 1997 Dearing Report allowed some universities to define themselves as "business-facing universities" as it defined universities as being places of research and advanced learning, and situated them at the edge of educational policy. Nevertheless, if we are to take into account that knowledge is at the root of economic prosperity, universities should also be at the heart of economic policy (this was implemented in the UK, for example, in the late 2000s, when the governmental Department responsible for higher education was also responsible for business).

\footnotetext{
${ }^{2}$ https://www.timeshighereducation.com/features/diversitychallenge/400160.article
} 
Given the large diversity of possible definitions, we should also mention the most popular one when it comes to pinpointing what a university is, namely the one expressed by the philosophical founder of the University of Berlin, Wilhelm von Humboldt. He argued (1903) that the teaching and research activities should take place in the same institution and be carried out by the same individuals. Moreover, it would be necessary for universities to tackle the issues that are not yet solved, be them in research or in teaching (in opposition to schools, which should only deal with the universally accepted and non-disputed knowledge). According to the German thinker, the best way in which universities can serve their community and the state is to suffer no interference from the state. Consequently, the entire university edifice is based on university autonomy and academic freedom. For Humboldt, all the knowledge is situated under philosophy's cupola. Humboldt was the one who opened the debate concerning the definition of the university, alongside its mission and roles in the community.

The university's mission is also a fundamental factor in defining and differentiating it from other institutions. Jose Ortega y Gasset remarked in 1930 that an institution cannot be configured as an assembly of practices unless, beforehand, it had defined rigorously and successfully its mission (Ortega y Gasset, 1999, p. 16). And in order to establish the mission of the university, Ortega y Gasset tried to identify its functions, namely: "transmission of culture", "teacher training", "scientific research and educating the new scholars".

The aforementioned THE article also quotes Leslie Wagner, who stated that "University is an elastic term, used by some to include and some to exclude." If we are to rely on this, the possibilities of defining the university become almost infinite. However, we believe that a clear, consistent and transnational definition of universities would help in drafting policies in the field of higher education and in clarifying the meaning of "higher" from "higher education". Despite the potential variations in definitions, a number of fundamental axioms remain central for the mission of any university, namely the freedom of expression within the limits of the law, the freedom of thinking within the society's ethical framework and the freedom to question universally accepted axioms. Lord Dearing suggested that similar to the manner in which medieval communities were built around castles, the castles of 
the future who will "feed" the communities from an economic and cultural point of view are the universities.

\section{Methodology \\ Sample selection}

In Romania, according to the provision of Law no. 1/2011 (also known as National Education Law), each university can initially vote (through a referendum) for the manner of electing their rector (either by an electoral vote or through a selection process administered by a specially appointed committee). All universities we included in the sample opted for electing their rector. Thus, candidates had to submit a "Managerial Programme" alongside their CV. A number of debates between candidates were also organised in some universities.

For the purpose of this article, we selected the top six universities in the country from the point of view of their performance. On the one hand, we included all the universities from the Universitaria Consortium (in alphabetical order: Alexandru Ioan Cuza University of Iași/UAIC, Babeș-Bolyai University of Cluj-Napoca/UBB, Bucharest University of Economic Studies / ASE, University of Bucharest/UB and West University of Timișoara/UVT), i.e. one specialised institution in business and economics - ASE and four comprehensive universities; on the other, we also included in the sample Politehnica University of Bucharest/UPB because of its overall performance in the 2016 Romanian University Metaranking (available in Romanian here). UPB ranks third at country level, the remaining top five positions being held by the comprehensive universities of the Universitaria Consortium. The slightly lower position of ASE can be explained through the fact that it is a specialised institution, not a comprehensive one, and thus it might not be visible in all international rankings, which cover a large variety of fields.

Starting from the selected universities, we identified the managerial programmes of the candidates in the 2016 elections (all programmes were accessed during 2016). We selected only the programmes drafted by the ones who won the elections, on the presumption that these programmes included concepts regarding the university that resonated with a wider part of the academic community. 
In total, we analysed 6 managerial programmes trying to identify as many defining characteristics of a university as possible, but starting from the defining elements identified in the literature. Some of the programmes also belong to rectors in office running for a new term; however, we did not differentiate them among the sample, and we referred to all their authors as "aspiring" or "future" rectors (even though some of them had already been in office for one term).

\section{Text analysis}

We analysed the manifestoes in the sample initially using the floating reading (Moscovici \& Buschini, 2007), in order to identify to what extent the elements of the definition of the university (from the literature review) appear. As stated before, the definition of the university consists both of century-old elements (such as the marriage between teaching and research) and of newer elements (such as thirdstream activities). After identifying their presence (or absence), we commented on the possible implications these entail. Then we explored the presence and/or absence of additional elements pertaining to the most used elements associated with the university (for example, the international league tables), discussing them in turn, as well.

\section{Findings}

Half of the analysed manifestoes explicitly referred to the university as an "academic community", not just another (public) institution. The university seen as community is a key element, present in connection to the academic institution from its very beginning. The manifestoes showed explicit awareness of the university being more than just its institutional structure. Moreover, most of them also included students in this community. However, there is an explicit difference being often made between academics and researchers (intrinsic part of the community) versus administrative staff (which only supports the aforementioned community).

Research is the second key element to be found in connection to what a university is throughout the centuries (de Ridder-Symoens, 
1992). Naturally, the reach of science has greatly expanded over centuries, but research as such is one of the pillars at the foundation of any university. As such, research is a topic that is found across all manifestoes analysed. It is considered important in all its aspects, starting from policy, going through funding and quality assurance and ending with its overall potentially beneficial impact on the university as a whole. Research is recognised as something that needs to be nurtured, assumed and, at the same time, laid at the basis of all the other activities of the university. This is potentially explained also through the former political background of the country, namely the fact that in communist times, research had been taken out of universities and research activities were strictly supervised. Nowadays, research seems to take an increasingly stronger hold in the Romanian universities included in the analysed sample, with all candidates recognising its important role and positive outcomes. Many a time research is also linked with innovation, excellence and better funding.

The fact that research is featured so frequently and almost universally in all electoral manifestoes analysed is no surprise, if we are to consider the performance of the respective universities in international rankings (many of which including indicators linked directly to research outcomes). In its turn, this also entitles for high expectations for their respective universities - given that these universities are the most performant at national level, many manifestoes mention a increased international visibility (alongside internationalisation of studies and, sometimes, better performance in international rankings.) There are voices in literature (for example, Liessmann, 2009, p. 9-10), who argue that rankings, improperly approached, could bring more harm than benefit to a university, for example suffocating its academic freedom, especially when they are allowed to become instruments of external control. If it only wants to achieve a good position in the international rankings, the university could run the risk of using only these for reference, and this lose sight of its true roles and functions.

Naturally connected to research, knowledge is also an important factor, considered explicitly linked to the university is all of the manifestoes from the sample. The university is not only the depositary of knowledge (and the one passing it forward to future generations), but also the one which discovers new knowledge and the one which 
applies existing knowledge in new, innovative manner. These findings mirror to a great extent the connection between the university and knowledge investigated by the philosopher Ortega y Gasset (1999). He found several types of relationship, namely: the university is the depository of knowledge as well as a generator of new knowledge; at the same time, the university filters the knowledge through a filter, that is dependent on the social, economic and political context, before multiplying it and disseminating it towards others. In Ortega Y Gasset's words: one of the fundamental functions of a university is to "create a cultivated individual, which sees their path in life in a clear light" (1999, p. 79-80).

The future university leaders are also concerned with the training of students - but with only some of them approaching the concept of educating the individual as a whole, and not just in their individually chosen field of study. Some manifestoes include the fact that the university should train not only specialists in a field, but well-rounded citizens of the world of tomorrow.

Education is one of the prevailing topics of all electoral manifestoes, permeating all the topics addressed by the candidates. This ties in closely with the concept of Bildung, defined in literature most often as not just the simple confrontation of individual students with the subject studied, but also as their active participation to an educational community (in the sense used by Newman, for example), thus contributing, at the same time, at the formation and modelling of the community of which they are part of. The debate regarding the role of higher education institutions and training/education (understood as Bildung) and the relationship of the individual with knowledge is still going on nowadays, even though it started more than two centuries ago. In Theorie der Unbildung (2008), Liessmann talks about three possible embodiments of the concept: Bildung, Halbbildung and Unbildung. In Liessmann's view, the issue today is not a degradation of the idea of Bildung, but rather the lack of a normative idea of education. Bildung is no longer an objective and a measure in producing science, in learning and in teaching. And the result of this loss is that education has reduced its scope, and science and knowledge have been degraded to just a measurable indicator for human capital. We feel that a familiarity of the entire academic community and even the possible inclusion among a university's objective of Bildung (and not just various aspects of 
education and training) would bring added value to the overall institutional performance.

The aspiring leaders see the university as one connected to its community in one form or another, be it more closely, through third stream activities, or more loosely, as a minimum reaction to today's general socio-economic context. It is clear that neither of the candidates see the university as the medieval Ivory Tower, a seat of learning which was not interested in any connections with the outside world. Two such manifestoes take the university's role even a step further, configuring it as a "public intellectual" (through its academics), actively engaged in the debates in the public sphere. As the university has a privileged relationship with knowledge (and one could even extrapolate this to truth), it is the one bearing the responsibility to educate not only the students enrolled in its courses, but also the society at large for everyone's (current and future) benefit.

A university being a "public intellectual" ties in with the cultural function of the university. Seen at the intersection of the university's relationship with knowledge, on one hand, and with its community, on the other, the cultural function of the university is to be found at the centre of the three traditional universities functions, namely teaching, research and third-stream activities. A university's cultural function usually includes: (i) setting professional standards, (ii) acting as a cultural filter, (iii) being a pro-active communicator, (iv) being a public intellectual, assuming both the role of consciousness and critic within society, (v) the university as a creator of social citizens, (vi) the university as an innovation generator and (vii) the university as a generator of national intelligence. We can safely read in-between the lines of the mentioned manifestoes that all these components mentioned above are closely tied to the university's role as public intellectual, and are implicitly (and concerning specific aspects, explicitly) connected to it.

Student training is closely linked to ensuring the infrastructure required for higher quality education and training. Approaches to infrastructure vary widely, from one approaching the topic only at the level of principle to a completely opposite one, mentioning is minute detail what improvements are going to be made to what specific buildings and laboratories. 
There was no lengthy mention of diplomas (except for the case of double and joint degrees). Degree-granting power is one specific characteristic of a university, yet the manifestoes analyses did not approach the topic. One possible explanation could be that the diplomas for degrees are granted jointly by the university and the national Ministry of Education, and thus the university's responsibility could be perceived as being reduced.

Moreover, maybe a sign of our times, there is no mention of universal knowledge. Naturally, it is impossible to achieve as such nowadays, but it should be replaced at least with an attempt at a global vision and/or understanding of the field of knowledge one is part of. The university seems to be losing its universal reach, increasingly becoming a fragmenversity. Comprehensive universities are still further from running this risk than specialised universities. The university may be intrinsically connected to knowledge in a variety of ways, but not to universal knowledge any-more. Specialisation in one field or another is encouraged, alongside multi- and pluri-disciplinarity. We may infer from in between the lines that all manifestoes authors are aware that today there is no one person able to accumulate the entire knowledge existing on the planet.

The manifestoes assume an intrinsic academic freedom for the universities, while recognising possible vulnerabilities (especially connected to the unpredictable financial and legislative aspects). All candidates include reactive responses of universities to their environment, but only some (about half from the sample) suggest proactive actions as well, such as assuming an active role as a public intellectual or lobbying for specific provisions of legislation.

\section{Conclusions}

The electoral manifestoes analysed cover many of the elements defining a university, even though in variable proportions. However, there is an obvious absence of conceptualising the university at its more abstract levels. Most of the time, the electoral manifestoes seem to assume that the definition of the university is common-sense, and is shared by all its actors and stakeholders. The majority of programmes speak about what a university does, or how it relates to its various stakeholders, but do 
not to define what they understand by "university", as the very essence of the concept, or the individual's understanding of the institution. Further work could explore in more depth this aspect, given that the literature addressing it covers entire centuries, and the presence of a commonly shared understanding (in the shape of a definition) could only be beneficial.

One could argue that a leader who is familiar with such as idea, mission, vision, values and the like would bring an added value to their term in office; however, we consider these to be fundamental concepts alongside an understanding of what the university is (or should be) and what it does (or it should do) to any successful term in office.

One can set many aims and objectives for any type of institution but as long as they do not define their understanding of the institution clearly (and currently this is probably due to the existing legislation), they will lack the complete understanding of how those aims and objectives can be actually reached. If one was to focus exclusively only on details and missing the global concept would be a classic case of "not seeing the forest for the trees". Consequently, we believe that a full understanding of the university, included explicitly, and not only implicitly in electoral manifestoes, which later have the potential of becoming standards for institutional, more detailed strategies, programmes and measures, should also be as detailed and as literaturegrounded as possible.

Understanding such global concepts connected to the university (what it is, what it does, intrinsically) would help consistently both any future person holding a position of leadership and the university itself in orienting desired courses of action. A self-reflexive university that understand its essence through its actors and stakeholders could define easier a (better) destination for its future. 
98 • Journal of Research in Higher Education • Vol. I, No. 2, 2017

\section{References}

Bojan, Cristina. Pavlenko, Sonia, (2013) "Devenim mai înţelepţi prin educaţie universitară? Despre educaţie, cunoaştere şi înţelepciune", in Ţîrău Liviu, Melancu Ştefan (ed.), Interferenţe euro-atlantice. 20 de ani de Studii Europene la Universitatea BabeşBolyai, EFES, Cluj-Napoca, pp.144-154.

de Ridder-Symoens, Hilde (ed.) (1992): A History of the University in Europe. Vol. I: Universities in the Middle Ages, Cambridge University Press.

Hilbert, Martin, Lopez, Priscila, (2011). “The World's Technological Capacity to Store, Communicate, and Compute Information", Science, 332, 60, DOI: 10.1126/science.1200970.

Horlacher, Rebekka (2011), Bildung, Haupt Verlag, Göttingen.

Humboldt, Wilhelm von (1903), "Uber die innere und aussere

Organisation der hoherren wissenschaftlichen Anstanlten in

Berlin", Gesammelte Schriften, vol. 10, B. Behr's Verlag, Berlin.

Michaelis, Johann David (1772); Raisonnement über die protestantischen

Universitäten in Deutschland, Frankfurt und Leipzig.

Milward, Peter (2006), What is a University?, Shepheard - Walwyn Publishers Ltd, London.

Moscovici, Serge. Buschini Fabrice (coord.) (2007) Metodologia ştiinţelor socioumane, Iaşi: Polirom.

Newman, John Henry, (1996) The Idea of a University Defined and Illustrated I. In Nine Discourses Delivered to the Catholics of Dublin

II. In Occasional Lectures and Essays Addressed to the Member of the Catholic University, Longmans, Green and Co., London.

Ortega y Gasset, Jose (1999), Misiunea Universității, translated by Andrei Ionescu, Univers, București.

Pavlenko, Sonia (2015) Ideea de Universitate,, Cluj-Napoca: Presa Universitară Clujeană.

Pavlenko, Sonia, Bojan, Cristina (2013) "Exercising Democracy in Universities: The Gap between Words and Actions", AUDEM The International Journal of Higher Education and Democracy, Volume 4, p. 26-37 DOI:10.1353/aud.2013.0008, available at: http://muse.jhu.edu/login? 
auth=0\&amp;type=summary\&amp;url=/journals/audem/v004/4.pavle nko.pdf.

Pârvan, Vasile, (1919), Datoria vieții nostre, speech given at the inauguration of University of Cluj, available online https://ro.wikisource.org/wiki/Datoria_vie $\% \mathrm{C} 8 \% 9 \mathrm{Bii}$ noastre.

University. (n.d.). Oxford Dictionary. Retrieved December $2^{\text {nd }}, 2017$, from https://en.oxforddictionaries.com/definition/university. http://www.unibuc.ro/n/despre/alegeri/Alegeri 2015.php https://www.uvt.ro/ro/alegeri-2016-2020/ http://www.ase.ro/2013ffiles/legislatie/Program/Program\%20de \%20management\%20Rector\%20\%202016-

2020\%2010\%20febr..pdf http://www.uaic.ro/alegeri-2016/ http://www.upt.ro/Informatii 2016---2020-alegerea-rectoruluiupt 835 ro.html

http://www.ubbcluj.ro/ro/infoubb/alegeri UBB. 
